\title{
Tibuana
}

\section{DESIGN "SANGRAI" TOOL FOR COFFE WITH STIRER FIN}

\author{
Djoko Adi Waluyo ${ }^{1}$, Yanatra Budi Pramana ${ }^{2}$ \\ Industrial Engineering Department, Faculty of Industrial Technology ${ }^{1,2}$ \\ University of PGRI AdiBuana Surabaya \\ email : djokoadiwalujo@unipasby.ac.id
}

\begin{abstract}
Coffe is one of the results of the commodity plantation that has a fairly high economic value among other crops and plays an important role as a source of foreign exchange, to create a taste of coffee and sold on the market, the important things are the selection of coffee beans and roasting processes. The tools currently existing are still roasted manually and semi-automatic. This research aims to design the tool automatic coffee roast system, analysis the feasibility roasted include capacity analysis.
\end{abstract}

Keywords:

Tools, Mixer Series, Roasted Coffee Beans, Roasting.

\section{INTRODUCTION}

Indonesia is known as the largest coffee producing country in the world after Brazil, Vietnam and Columbia. Coffee has been cultivated since the 15 th century, to date coffee is one of the most consumed beverages in addition to water and tea, and even drinking coffee today is considered a modern lifestyle (Gardjito and Dimas, 2011). Some coffee industries have begun using machine technology in their production process.

This is done in addition to obtaining optimum yields also creates a delicious taste of coffee and sells in the market, but in many regions in Indonesia there are still many who use manual methods in working on the production process, including home industry and coffee shop. One of the coffee production processes that require technology and is the key to the process of producing ground coffee is the process of "penyangraian". Coffee brewing is basically a process of altering the chemistry and the physicality of the coffee property (Ginting, 2013).

This process is the stage of formation of the aroma and taste of typical coffee from the coffee beans with heat treatment. Coffee beans naturally contain enough organic compounds to form the taste and smell of coffee. Roasting time is determined by the color of roasted coffee beans or often called degrees of roasting.

The longer the roasting time, the color of roasted coffee beans approaching darkish blackish brown (Widyotomo., et al 2006), swelling, evaporation of water, the formation of volatile compounds, caramelization of carbohydrates, reduction of coarse fiber, protein denaturation, the formation of gases as a result of oxidation and the formation of a characteristic aroma in coffee occurs during the process of "penyangraian" (Ciptadi., et al 1985).

From the above problem, this research intends to design the appliance of coffee system automatic roaster and analyze the feasibility of the developed tool. Feasibility analysis of the tool includes tool capacity analysis and ease of operation analysis tool. 


\section{Tibuana}

\section{METODS}

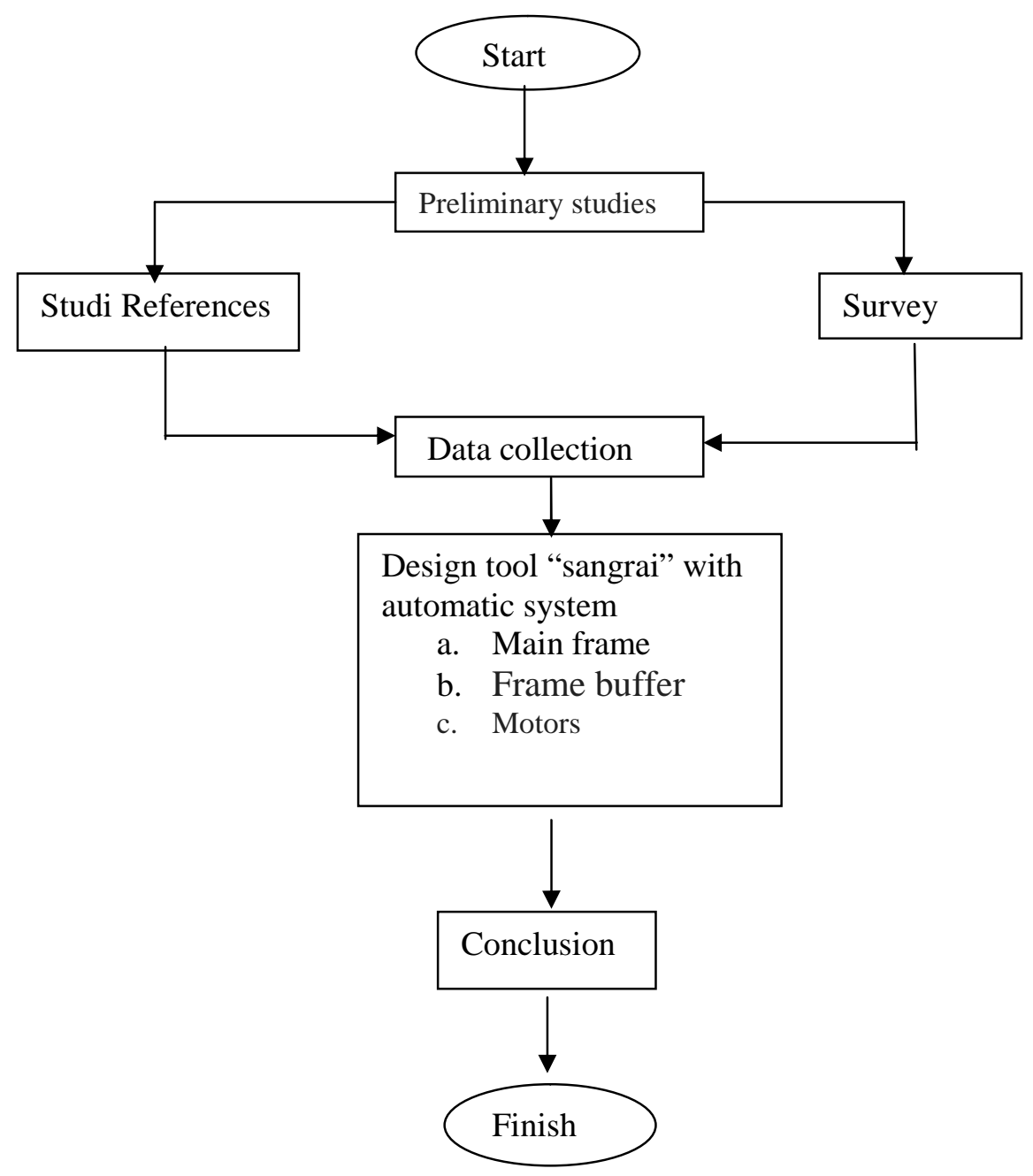

Figure 1. Flowchart research

\section{RESULT AND DISCUSSION}

Coffee roasting appliance component:

a. Main Frame: serves as the component of all components, this frame is made of iron elbow plate, because this plate is commonly used for the frame.

b. Frame buffer: acting as a stove buffer to support LPG stove.

c. Motor drive: serves as a prime mover of the coffee rooster peeler, motor drive in the form of a DC motor fan, because this bike is cheap and lighter than diesel engines

d. Motor dc fan: acts as a transmission link on the motor, this machine is made of $\mathrm{dc}$ motor motor that is installed in the fan.

e. Chain: serves to connect to one gear with another.

f. Gear: serves as a chain link with As pedals stirring coffee, because it uses teeth and chains, and allows long distance. 


\section{Tibuana}

Journal of applied Industrial Engineering-University of PGRI Adi Buana

p-ISSN 2622-2027

$e$-ISSN 2622-2035

g. As pedals: to move the stirrer fins up and down in order to roast the coffee in a clay pan.

h. Stirring fins: fin stirrer to stir the coffee brewing on a burnt ground furnace to mature evenly.

Table 1. Tools and materials

\begin{tabular}{ccc}
\hline No & Tools & Materials \\
\hline 1 & Grinders & Iron elbow \\
2 & Sketmatch & Stainless \\
3 & Electric welding machine & Nut and bolt \\
4 & Wrench 12/14 & As pedal \\
& & \\
5 & Pemotong besi & Iron cutters \\
6 & Elbow ruler & Gears \\
7 & Hammer & Velg \\
\hline
\end{tabular}

Table 2 Material Cost

\begin{tabular}{|c|c|c|c|c|}
\hline Raw materials & Unit & Price & Material & Total \\
\hline Iron elbow & $1 \times 3$ meter & Rp. $60.000,00$ & 6,5 Meter & Rp.160.000,00 \\
\hline LPG Stoves & 1 unit & Rp. $100.000,00$ & 1 unit & Rp.100.000,00 \\
\hline Velg plastic & 1 unit & Rp. $75.000,00$ & 1 unit & Rp. $75.000,00$ \\
\hline Large Wheel & 1 unit & Rp. $35.000,00$ & 1 unit & Rp. $35.000,00$ \\
\hline Small Wheel & 1 unit & Rp. $30.000,00$ & 1 unit & Rp.30.000,00 \\
\hline Stainless Steel & $1 \times 2$ meter & Rp. $40.000,00$ & $2 \times 50 \mathrm{~cm}$ & Rp. $40.000,00$ \\
\hline Wok frying pan & 1 unit & Rp. $85.000,00$ & 1 unit & Rp. $85.000,00$ \\
\hline Chain Gear small & 1 unit & Rp. 50.000,00 & $\begin{array}{c}2 \text { Gear small \& } \\
\text { large }\end{array}$ & Rp. $50.000,00$ \\
\hline Motor Dc fan & 1 unit & Rp. $60.000,00$ & 1 unit & Rp. $60.000,00$ \\
\hline Fin mixer & 1 unit & Rp. $30.000,00$ & 2 unit & Rp. $30.000,00$ \\
\hline As Pedals & 1 unit & Rp. $45.000,00$ & 1 unit & Rp. $45.000,00$ \\
\hline Design stove buffer & 1 unit & $\mathrm{Rp} 40.000,00$ & 1 unit & Rp. $40.000,00$ \\
\hline \multirow[t]{2}{*}{ LPG stove hose } & 1 unit & Rp. $60.000,00$ & 1 unit & Rp. $60.000,00$ \\
\hline & & & Total & $800.000,00$ \\
\hline
\end{tabular}




\section{Tibuana}

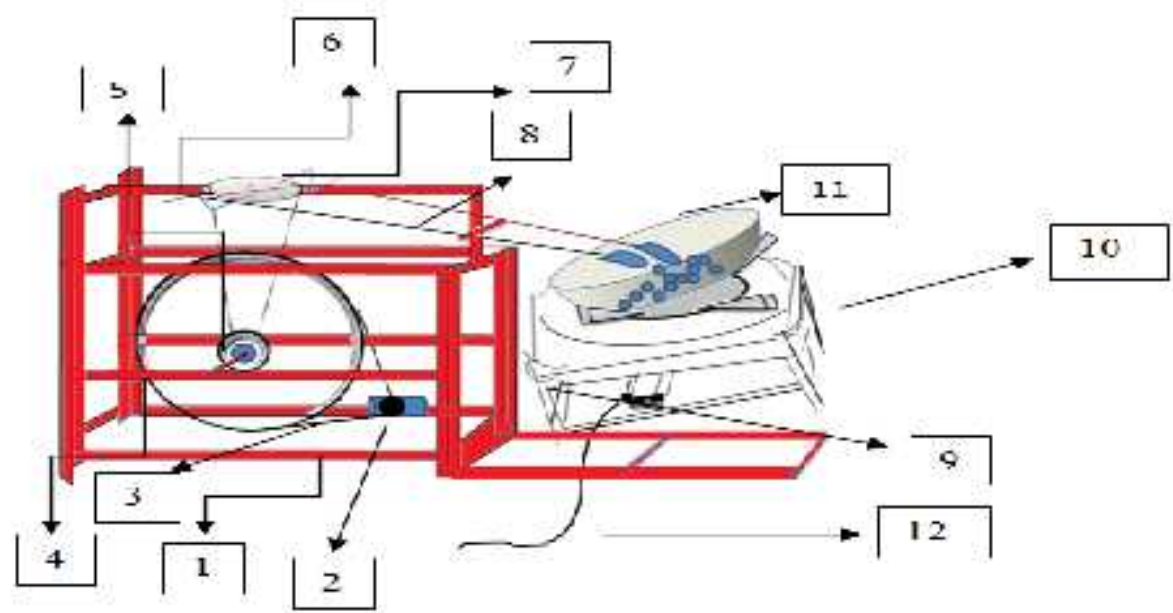

Figure 2. Coffee Roasting Device Design

Information from Fig 2.

(1) Main Frame

(2) Motor Dc fan

(3) Driving chain

(4) Velg

(5) Small wheel

(6) Large wheel

The design of this coffee roasting machine will work when the motor is powered by an electric current so that the bias motor moves the existing small gear, Then it will move the large gears so that the large gears move then As the pedal can move, so the bias stirrer fins move following the spin As pedals that lap up roasting tool developed in this study. Here are the respondents' results on the

1. Equipment Feasibility Analysis

In the feasibility analysis this tool involves 10 kinds of coffee beans, with two coffee roaster machines as a comparison. The first tool is a coffee roaster that is on the market, while the
(7) As Pedals

(8) Filler stirrer

(9) Stove LPG

(10) Frame buffer

(11) Frying pan from clay

(12) Hose stove LPG

and down. Then the stirrer fins will stir the coffee to be roasted in a roasting pan that is heated with LPG gas stove.

In the feasibility analysis this tool involves 10 respondents, with two coffee roasting machines in comparison. The first tool is a coffee roaster tool in the market, while the second tool is a coffee capacity and ease of operation of both devices.

second tool is a coffee roaster tool developed in this study. The following are the results of respondents to the capacity and ease of operation of the two devices.

Tabel 3. Analysis Tool Capacity

\begin{tabular}{|c|c|c|c|}
\hline No & Name & Tool I 15 g coffee (10 Minute) & Tool II 15 g coffee (10 Minute) \\
\hline 1 & Luwak & $\begin{array}{ll} & \text { Ons } \\
\end{array}$ & 7 Ons \\
\hline 2 & Arabika & Ons & Ons \\
\hline 3 & Robusta & Ons & Ons \\
\hline
\end{tabular}




\section{Tibuana}

Journal of applied Industrial Engineering-University of PGRI Adi Buana

p-ISSN 2622-2027

$e$-ISSN 2622-2035

\begin{tabular}{ccclcl}
\hline 4 & Excelsa & 10 & Ons & 13 & Ons \\
5 & Jawa & 11 & Ons & 15 & Ons \\
6 & Gayo & 15 & Ons & 15 & Ons \\
7 & Toraja & 15 & Ons & 15 & Ons \\
8 & Sumatra & 15 & Ons & 15 & Ons \\
9 & Sidikalang & 15 & Ons & 15 & Ons \\
10 & Arang & 15 & Ons & 15 & Ons \\
\hline
\end{tabular}

\section{CONCLUSION}

From the tool capacity analysis is known: for every 15 grams of coffee within 10 minutes the operator produces a roasted coffee

\section{REFERENCES}

1. Ginting, W. (2013). "Rancang Bangun Alat Penyangrai Kopi Mekanis Tipe Rotari".

2. Widyotomo, S dan Mulato, S. (2003 ). "Pelatihan Dasar Uji Cita Rasa Kopi" Warta Pusat Penelitian Kopi dan Kakao Indonesia.

3. Ciptadi dan MZ Nasution ,(1985). "Pengolahan Kopi Agro Industri” , Press.Bogor of 8.77 ounces on the first device and 13 ounces on the second device.

4. Mulato, S. 2006. "Perkembangan Teknologi Pengolahan Kakao di Indonesia”. Pusat Penelitian Kopi dan Kakao. Jember.

5. Rahardjo, Pudji. 2012. "Panduan Budidaya dan Pengolahan Kopi Arabika dan Robusta”. Penebar Swadaya. Jakarta. 